\title{
Honey Supplementation in Spontaneously Hypertensive Rats Elicits Antihypertensive Effect via Amelioration of Renal Oxidative Stress
}

\author{
Omotayo O. Erejuwa, ${ }^{1}$ Siti A. Sulaiman, ${ }^{1}$ Mohd S. Ab Wahab, ${ }^{1}$ Kuttulebbai N. S. Sirajudeen, ${ }^{2}$ \\ Salzihan Salleh, ${ }^{3}$ and Sunil Gurtu ${ }^{4}$ \\ ${ }^{1}$ Department of Pharmacology, School of Medical Sciences, Universiti Sains Malaysia, Kelantan, \\ 16150 Kubang Kerian, Malaysia \\ ${ }^{2}$ Department of Chemical Pathology, School of Medical Sciences, Universiti Sains Malaysia, Kelantan, \\ 16150 Kubang Kerian, Malaysia \\ ${ }^{3}$ Department of Pathology, School of Medical Sciences, Universiti Sains Malaysia, Kelantan, \\ 16150 Kubang Kerian, Malaysia \\ ${ }^{4}$ Jeffrey Cheah School of Medicine and Health Sciences, Monash University Sunway Campus, Jalan Lagoon Selatan, \\ Selangor, 46150 Bandar Sunway, Malaysia \\ Correspondence should be addressed to Omotayo O. Erejuwa, erejuwa@gmail.com
}

Received 1 August 2011; Revised 5 September 2011; Accepted 25 September 2011

Academic Editor: Florian Lang

Copyright ( $\odot 2012$ Omotayo O. Erejuwa et al. This is an open access article distributed under the Creative Commons Attribution License, which permits unrestricted use, distribution, and reproduction in any medium, provided the original work is properly cited.

\begin{abstract}
Oxidative stress is implicated in the pathogenesis and/or maintenance of elevated blood pressure in hypertension. This study investigated the effect of honey on elevated systolic blood pressure (SBP) in spontaneously hypertensive rats (SHR). It also evaluated the effect of honey on the amelioration of oxidative stress in the kidney of SHR as a possible mechanism of its antihypertensive effect. SHR and Wistar Kyoto (WKY) rats were randomly divided into 2 groups and administered distilled water or honey by oral gavage once daily for 12 weeks. The control SHR had significantly higher SBP and renal malondialdehyde (MDA) levels than did control WKY. The mRNA expression levels of nuclear factor erythroid 2-related factor 2 (Nrf2) and glutathione Stransferase (GST) were significantly downregulated while total antioxidant status (TAS) and activities of GST and catalase (CAT) were higher in the kidney of control SHR. Honey supplementation significantly reduced SBP and MDA levels in SHR. Honey significantly reduced the activities of GST and CAT while it moderately but insignificantly upregulated the Nrf2 mRNA expression level in the kidney of SHR. These results indicate that Nrf2 expression is impaired in the kidney of SHR. Honey supplementation considerably reduces elevated SBP via amelioration of oxidative stress in the kidney of SHR.
\end{abstract}

\section{Introduction}

Cardiovascular disease (CVD) is a main cause of death globally. The high incidence of CVD is ascribed to the increasing prevalence of modifiable cardiovascular risk factors such as hypertension, diabetes mellitus, obesity, lipid abnormalities, smoking, and sedentary lifestyle [1]. Epidemiological studies indicate that hypertension is a major public health concern not only because of its high prevalence but also being an important risk factor for the development of CVD, end-stage renal disease, stroke, and death [2-4]. Over the past decade, the role of reactive oxygen species (ROS) and/or reactive nitrogen species (RNS) in hypertension has been a subject of much research interest. ROS/RNS play an important role in the pathogenesis of hypertension [5] and are also associated with elevated blood pressure [6]. Evidence from literature suggests that elevated levels of ROS/RNS cause oxidative stress which is an important mediator in the imbalance between vasoconstrictor and vasodilator mechanisms in both experimental and human hypertension [5, 7-9]. In response to various oxidants, antioxidant enzymes undergo differential regulation or modulation [10-12]. These changes 
usually occur in the form of upregulation or downregulation of the activities and expressions of antioxidant enzymes; the main purpose is to protect against oxidative damage [10-12].

These experimental and clinical findings which implicate a role of oxidative stress in hypertension have resulted in a vast interest in therapeutic approaches or interventions that target oxidative stress in the treatment of hypertension $[13,14]$. Besides its sugar composition, honey consists of a number of bioactive compounds such as phenolic compounds, flavonoids, carotenoid-like derivatives, organic acids, Maillard reaction products, catalase, ascorbic acid, and other compounds which function as antioxidants [15]. Several therapeutic and medicinal effects such as antibacterial, antimutagenic, antiproliferative, hepatoprotective, hypoglycemic, and antioxidant effects have been ascribed to honey in recent years [16-21]. In contrast, there are limited or no available data on the effectiveness or efficacy of honey supplementation on elevated blood pressure. Recently, we reported that STZ-induced diabetes mellitus caused reduced SBP in SHR [12]. This hypotensive effect of diabetes on elevated blood pressure was also reported by other authors [22-24]. Besides, our study indicated that short-term (3 weeks) administration of Malaysian tualang honey in STZinduced diabetic SHR resulted in further reduction in SBP [12]. Since honey was not administered to nondiabetic SHR in that study [12], it is uncertain whether the reduction in SBP after honey supplementation is due to honey or secondary effect of diabetes mellitus. Therefore, this study was carried out to investigate the effect of Malaysian tualang honey supplementation on elevated SBP in nondiabetic SHR. We also evaluated the effect of this honey on amelioration of renal oxidative stress as a possible mechanism of its hypotensive or antihypertensive effect. Malaysian tualang honey is produced by the wild Asian bee (Apis dorsata). It gets its name from the tualang tree (Koompassia excelsa) which houses the hives of the bees. This tree can be found growing in the Southeast Asian rainforests of peninsular Malaysia, southern Thailand, northeastern Sumatra, Borneo, and Palawan.

\section{Results}

2.1. Effect of Honey on Systolic Blood Pressure in WKY and $S H R$. Figure 1 shows the systolic blood pressure (SBP) in control and honey-treated WKY and SHR. Before treatment, SBP was significantly $(P<0.01)$ higher in the SHR control than in the WKY control (Figure 1). Over the duration of treatment, the SBP was markedly $(P<0.01$ or $P<$ 0.01 ) higher in SHR while it remained constant in WKY. In contrast, there was a significant $(P<0.05$ or $P<$ 0.01 ) suppression of SBP in honey-treated SHR compared to SHR control. In SHR control, SBP at the end of the study was significantly $(P<0.05)$ higher than SBP before the commencement of the study (Figure 1). SBP was significantly $(P<0.01)$ lower in the honey-treated SHR than in the SHR control. Compared with control WKY, the honey-treated SHRs were still hypertensive. Honey supplementation did not affect SBP in WKY (Figure 1).
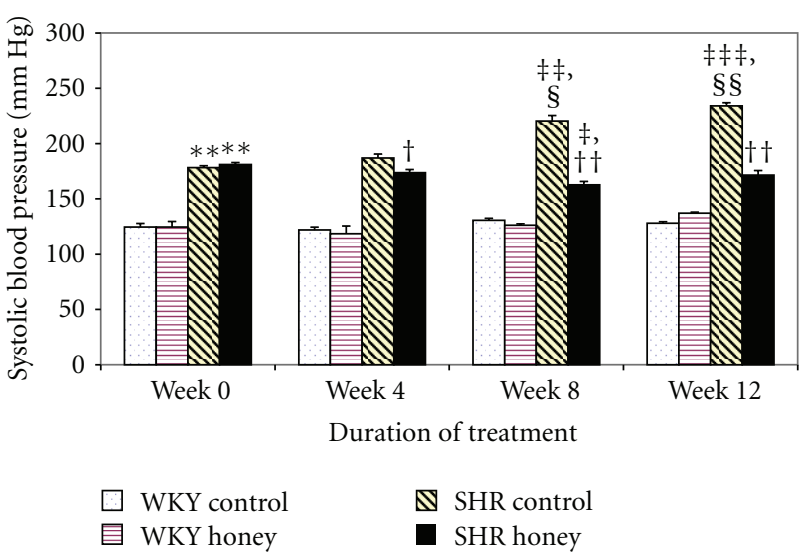

FIGURE 1: Effect of honey on systolic blood pressure in WKY and SHR during the treatment period. Each group consisted of six to seven rats. Data are expressed as mean \pm SEM. ${ }^{* *} P<0.01$ versus WKY control at the same week; ${ }^{\ddagger} P<0.05,{ }^{\ddagger \ddagger} P<0.01$, and ${ }^{\ddagger \ddagger} P<$ 0.001 versus the same group at week $0 ;{ }^{\S} P<0.05$ and $\$ \S P<0.01$ versus the same group at week $4 ;{ }^{\dagger} P<0.05$ and ${ }^{\dagger \dagger} P<0.01$ versus SHR control at the same week.

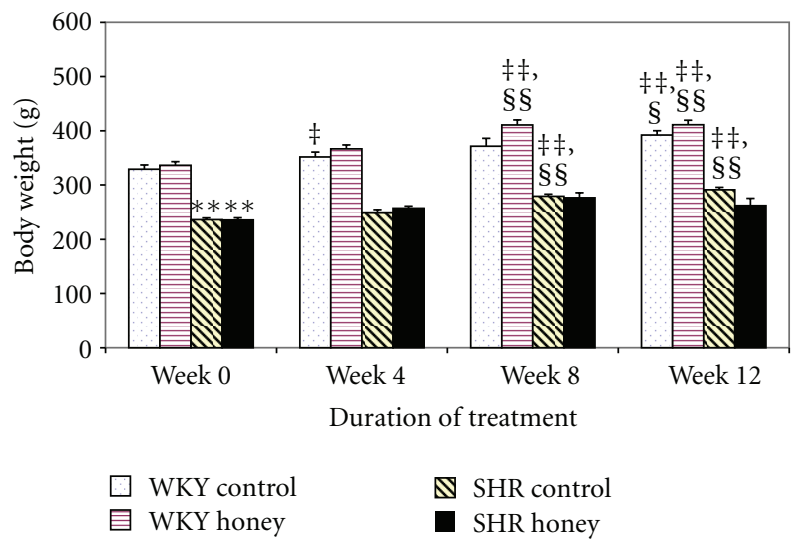

FIGURE 2: Effect of honey on body weight in WKY and SHR during the treatment period. Each group consisted of six to seven rats. Data are expressed as mean \pm SEM. ${ }^{* *} P<0.01$ versus WKY control at the same week; ${ }^{\ddagger} P<0.05$ and ${ }^{\ddagger \ddagger} P<0.01$ versus the same group at week $0 ;{ }^{\S} P<0.05$ and ${ }^{\S} P<0.01$ versus the same group at week 4 .

2.2. Effect of Honey on Body Weight in WKY and SHR. Figure 2 shows the body weight in control and honey-treated WKY and SHR before and after treatment. Before treatment commenced, control SHR had significantly $(P<0.01)$ lower body weight compared with control WKY. Over the duration of treatment, the body weight was markedly $(P<0.01$ or $P<0.01)$ increased in both WKY and SHR. Similarly, the body weight increased in WKY and SHR treated with honey. Supplementation with honey significantly $(P<0.05)$ increased body weight in WKY but not in SHR (Figure 2).

2.3. Effect of Honey on Oxidative Stress Markers in the Kidney of WKY and SHR. Figure 3 shows the MDA levels in control and honey-treated WKY and SHR. Control SHR had significantly $(P<0.05)$ higher MDA levels than did 


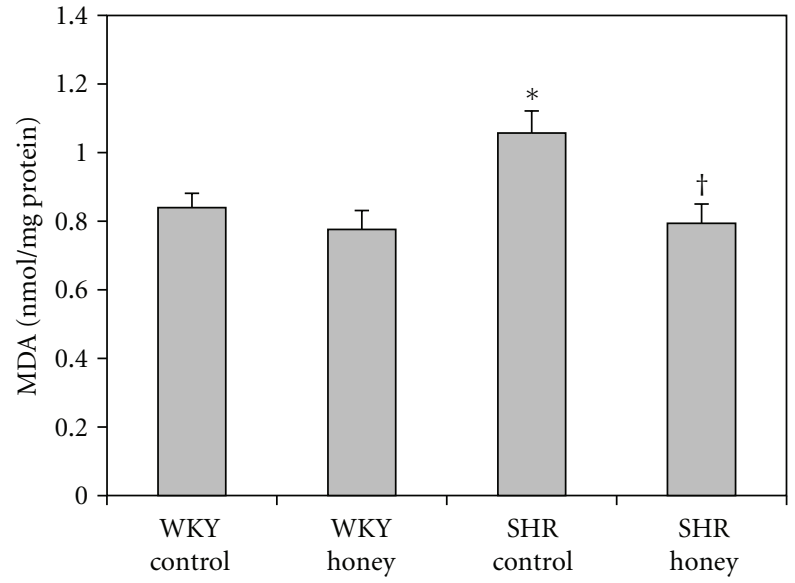

FIGURE 3: Effect of honey on malondialdehyde (MDA) in kidney of WKY and SHR. Each group consisted of six to seven rats. Data are expressed as mean \pm SEM. ${ }^{*} P<0.05$ versus WKY control; ${ }^{\dagger} P<$ 0.05 versus SHR control.

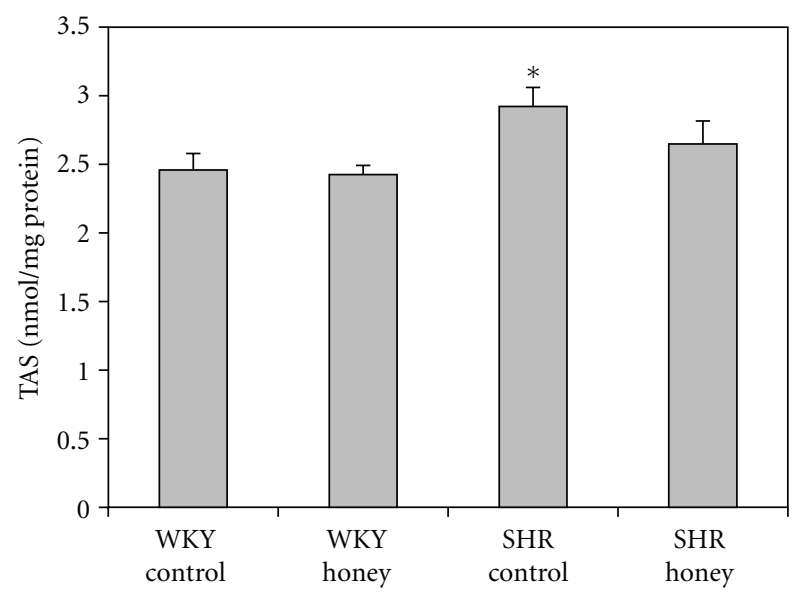

FIgUre 4: Effect of honey on total antioxidant status (TAS) in kidney of WKY and SHR. Each group consisted of six to seven rats. Data are expressed as mean \pm SEM. ${ }^{*} P<0.05$ versus WKY control.

control WKY. Honey supplementation did not affect MDA levels of the control WKY group but prevented the increase in MDA levels in SHR. Figure 4 shows the TAS in control and honey-treated WKY and SHR. TAS was significantly $(P<$ 0.05) higher in control SHR compared with control WKY. With honey treatment, TAS was reduced but not significantly in SHR. Table 1 shows the levels of reduced glutathione (GSH), oxidized glutathione (GSSG), and GSH/GSSG ratio in control and honey-treated WKY and SHR. The levels of GSH, GSSG, and GSH/GSSG ratio were similar in the control and honey-treated WKY and SHR (Table 1).

\subsection{Effect of Honey on the Activities of Antioxidant Enzymes in} the Kidney of WKY and SHR. Figure 5 shows the CAT activity in kidney of control and honey-treated WKY and SHR. Control SHR had significantly $(P<0.01)$ higher CAT activity compared with control WKY. With honey supplementation,

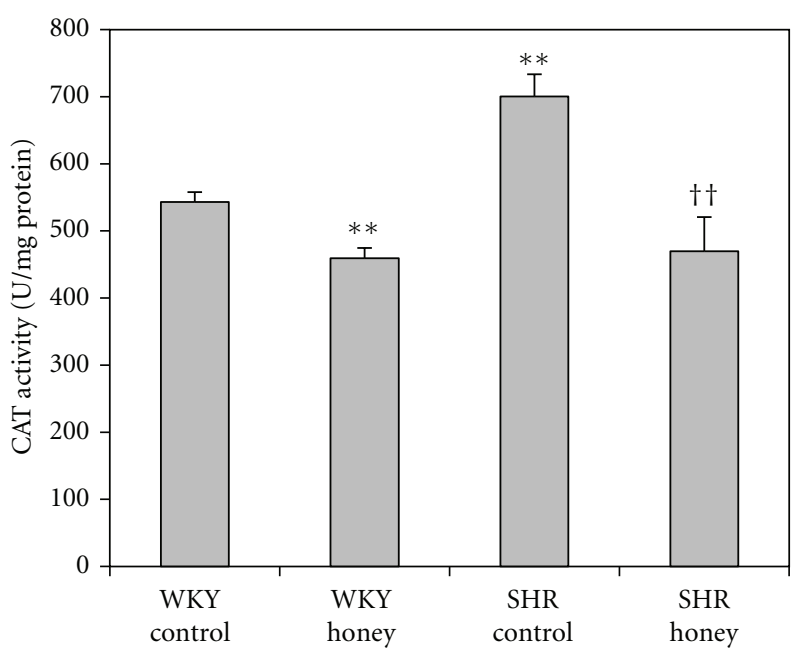

FIGURE 5: Effect of honey on catalase (CAT) activity in kidney of WKY and SHR. Each group consisted of six to seven rats. Data are expressed as mean \pm SEM. ${ }^{* *} P<0.01$ versus WKY control; ${ }^{\dagger \dagger} P<$ 0.01 versus SHR control. One unit of CAT is defined as the amount of enzyme that catalyzes the decomposition of $1 \mu \mathrm{mol}$ of $\mathrm{H}_{2} \mathrm{O}_{2}$ per minute.

CAT activity was significantly $(P<0.01)$ lower in honeysupplemented SHR compared with SHR control. Besides, honey treatment resulted in significantly $(P<0.01)$ lower CAT activity in WKY compared with WKY control. Figure 6 shows the GST activity in kidney of control and honeytreated WKY and SHR. Control SHR had significantly $(P<$ $0.01)$ higher GST activity compared with control WKY. With honey treatment, GST activity was significantly $(P<0.05)$ lower in SHR compared with SHR control. Table 1 shows the activities of superoxide dismutase (SOD), glutathione peroxidase (GPx), and glutathione reductase (GR) in control and honey-treated WKY and SHR. Activities of SOD, GPx, and GR were similar in the all the groups (Table 1).

2.5. Effect of Honey on the mRNA Expressions of Nrf2 and Antioxidant Enzymes in the Kidney of WKY and SHR. Figure 7 shows the mRNA expression of Nrf2 in kidney of control and honey-treated WKY and SHR. Control SHR had significantly $(P<0.05)$ lower mRNA expression of Nrf2 compared with control WKY. The administration of honey did not produce significantly higher mRNA expression of Nrf2 in SHR compared with SHR control. Figure 8 shows the mRNA expression of CAT in kidney of control and honey-treated WKY and SHR. The mRNA expression of CAT did not differ in control and honey-treated WKY and SHR. Figure 9 depicts the mRNA expression of GST$\alpha$ in kidney of control and honey-treated WKY and SHR. The mRNA expression of GST- $\alpha$ was significantly $(P<$ 0.01) downregulated in control SHR compared with control WKY. Honey supplementation in SHR did not significantly increase mRNA expression of GST- $\alpha$. Figure 10 shows the mRNA expression of GST- $\Pi$ in kidney of control and honeytreated WKY and SHR. Control SHR exhibited significantly $(P<0.01)$ downregulated mRNA expression of GST- $\Pi$ 
TABLE 1: The activities of antioxidant enzymes and markers of oxidative stress in kidney of WKY control, honey-treated WKY, SHR control, and honey-treated SHR.

\begin{tabular}{lcccc}
\hline & WKY control & WKY honey & SHR control & SHR honey \\
\hline SOD (U/mg protein) & $0.079 \pm 0.004$ & $0.071 \pm 0.008$ & $0.084 \pm 0.006$ & $0.082 \pm 0.008$ \\
GPx (U/mg protein) & $365.2 \pm 10.8$ & $356.9 \pm 10.0$ & $361.9 \pm 6.7$ & $366.0 \pm 19.0$ \\
GR (U/mg protein) & $172.2 \pm 4.9$ & $172.9 \pm 2.4$ & $177.8 \pm 5.5$ & $174.2 \pm 8.2$ \\
GSH (nmol/mg protein) & $0.192 \pm 0.020$ & $0.204 \pm 0.01$ & $0.219 \pm 0.019$ & $0.239 \pm 0.033$ \\
GSSG (nmol/mg protein) & $0.056 \pm 0.006$ & $0.064 \pm 0.007$ & $0.065 \pm 0.006$ & $0.065 \pm 0.007$ \\
GSH/GSSG & $3.46 \pm 0.50$ & $3.33 \pm 0.31$ & $3.44 \pm 0.30$ & $3.53 \pm 0.61$ \\
\hline
\end{tabular}

Each group consisted of six to seven rats. Data are expressed as mean \pm SEM. SOD: superoxide dismutase; GPx: glutathione peroxidase; GR: glutathione reductase; GSH: reduced glutathione; GSSG: oxidized glutathione. One unit of SOD is defined as the amount of enzyme required to exhibit $50 \%$ dismutation of superoxide radical. One unit of GPx/GR is defined as the amount of enzyme that catalyzes the oxidation of $1 \mathrm{nmol}$ of NADPH per minute.

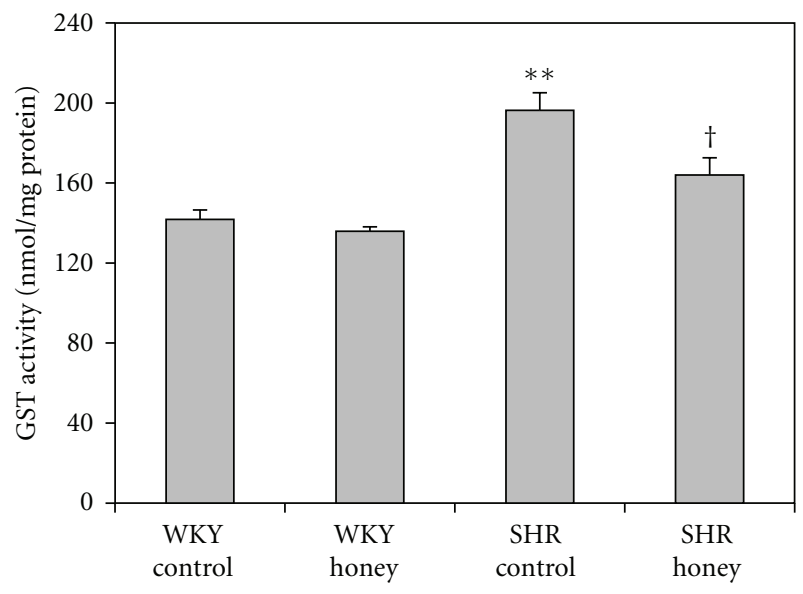

FIGURE 6: Effect of honey on glutathione-S-transferase (GST) activity in kidney of WKY and SHR. Each group consisted of six to seven rats. Data are expressed as mean \pm SEM. ${ }^{* *} P<0.01$ versus WKY control; ${ }^{\dagger} P<0.05$ versus SHR control. One unit of GST is defined as the amount of enzyme that catalyzes the conjugation of $1 \mathrm{nmol}$ of GSH-CDNB per minute.

compared with control WKY. In WKY, honey supplementation significantly $(P<0.05)$ downregulated mRNA expression of GST-П. The administration of honey to SHR did not significantly upregulate mRNA expression of GST$\Pi$. Table 2 shows that the mRNA expressions of CuZnSOD, MnSOD, and GPx in kidney of control and honey-treated WKY and SHR did not differ.

\section{Discussion}

The results indicated that SBP was significantly elevated in control SHR as previously reported $[13,14]$. Oxidative stress is implicated in the pathogenesis and/or maintenance of elevated blood pressure in hypertension [5-9]. Our data showed that SBP was significantly lower in the honey-treated SHR compared to control SHR. In contrast, no difference in SBP was observed in the honey-treated WKY rats compared to the control WKY rats. In view of the reported antioxidant effect of this honey $[20,21]$, our results are consistent with published data which demonstrate the beneficial effect of

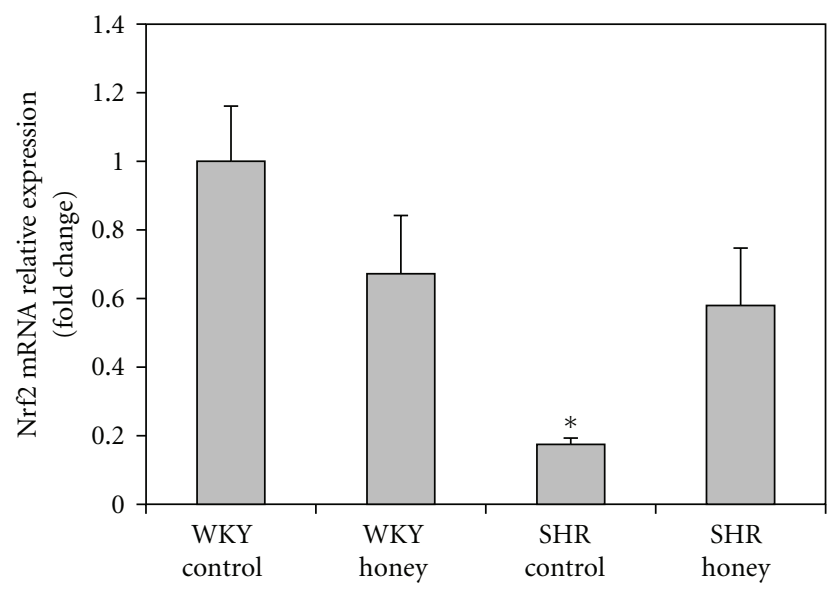

FIGURE 7: Effect of honey on mRNA expression of Nrf2 in the kidney of WKY and SHR. Each group consisted of four to five rats. Data are expressed as mean \pm SEM. The quantitative fold change in mRNA expression was determined relative to the $\beta$-actin mRNA levels in each corresponding group and calculated using the $2^{-\Delta \Delta C T}$ method. ${ }^{*} P<0.05$ versus WKY control.

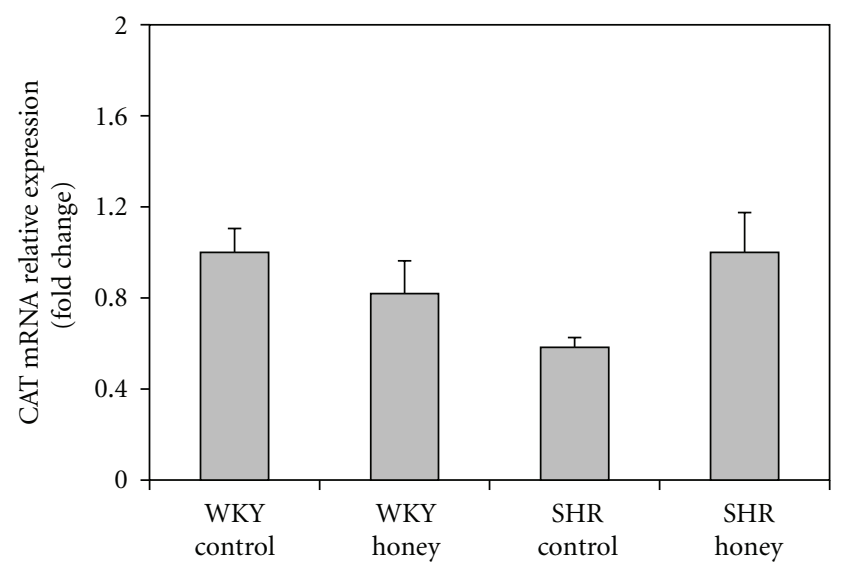

FIGURE 8: Effect of honey on mRNA expression of CAT in the kidney of WKY and SHR. Each group consisted of four to five rats. Data are expressed as mean \pm SEM. The quantitative fold change in mRNA expression was determined relative to the $\beta$-actin mRNA levels in each corresponding group and calculated using the $2^{-\Delta \Delta C T}$ method. 
TABLE 2: The mRNA expressions of CuZnSOD, MnSOD, and GPx in kidney of WKY control, honey-treated WKY, SHR control, and honeytreated SHR.

\begin{tabular}{lcccc}
\hline & WKY control & WKY honey & SHR control & SHR honey \\
\hline CuZnSOD & $1.00 \pm 0.16$ & $0.80 \pm 0.10$ & $0.19 \pm 0.03$ & $0.26 \pm 0.07$ \\
MnSOD & $1.00 \pm 0.06$ & $1.27 \pm 0.17$ & $0.74 \pm 0.10$ & $1.46 \pm 0.33$ \\
GPx & $1.00 \pm 0.14$ & $1.74 \pm 0.16$ & $0.53 \pm 0.05$ & $0.80 \pm 0.10$ \\
\hline
\end{tabular}

Each group consisted of four to five rats. Data are expressed as mean \pm SEM. CuZnSOD: copper-zinc superoxide dismutase; GPx: glutathione peroxidase. The quantitative fold change in mRNA expression was determined relative to the $\beta$-actin mRNA levels in each corresponding group and calculated using the $2^{-\Delta \Delta \mathrm{CT}}$ method.

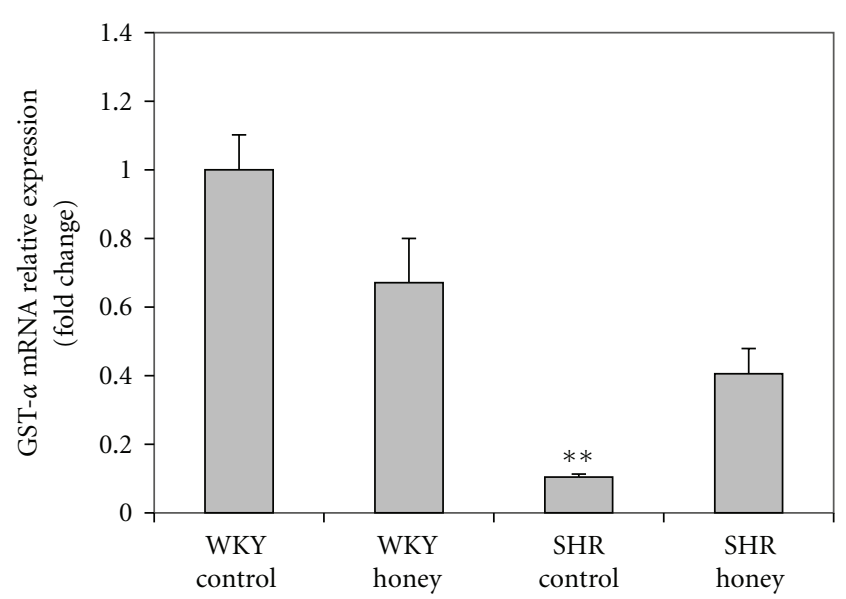

FIGURE 9: Effect of honey on mRNA expression of GST- $\alpha$ in kidney of WKY and SHR. Each group consisted of four to five rats. Data are expressed as mean \pm SEM. The quantitative fold change in mRNA expression was determined relative to the $\beta$-actin mRNA levels in each corresponding group and calculated using the $2^{-\Delta \Delta C T}$ method. $* * P<0.01$ versus WKY control.

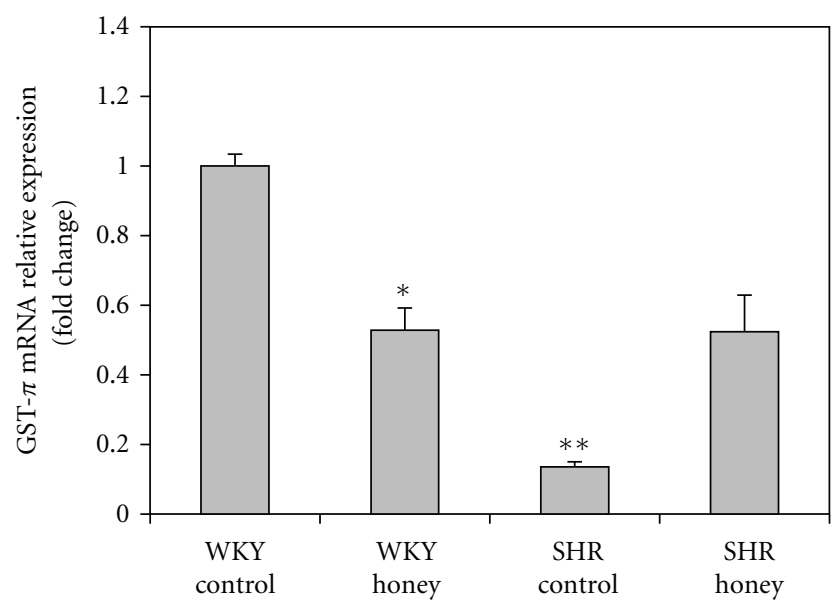

FIGURE 10: Effect of honey on mRNA expression of GST-П in kidney of WKY and SHR. Each group consisted of four to five rats. Data are expressed as mean \pm SEM. The quantitative fold change in mRNA expression was determined relative to the $\beta$-actin mRNA levels in each corresponding group and calculated using the $2^{-\Delta \Delta C T}$ method. ${ }^{*} P<0.05$ and ${ }^{* *} P<0.01$ versus WKY control. antioxidants on elevated blood pressure in SHR but not in normotensive WKY rats $[13,14]$. In addition to the role of renal oxidative stress in the pathophysiology of hypertension, the causal role of several other factors such as vascular oxidative stress [25], endothelial dysfunction [26], sympathetic nervous system [27], and renin-angiotensin system [28] is well recognized. Furthermore, a role of insulin resistance and other diabetic profile such as enhanced proteolytic activity and insulin receptor cleavage has been implicated in the pathogenesis of hypertension in SHR $[29,30]$. The fact that antioxidant (honey) supplementation, despite amelioration of renal oxidative stress, does not effectively restore SBP further lends credence to the notion that renal oxidative stress is not the only cause of elevated blood pressure in SHR and perhaps in human hypertension.

In many disorders (such as hypertension) associated with oxidative stress, the main ROS generated is superoxide anion $\left(\mathrm{O}_{2}{ }^{--}\right)[5,7,8] . \mathrm{O}_{2}{ }^{--}$generates a variety of other ROS which are of physiological importance [5, 7]. However, many tissues are endowed with antioxidant enzymes which play a key role in the detoxification of ROS. SOD protects tissues from oxidative stress and damage by catalyzing the conversion of $\mathrm{O}_{2}{ }^{--}$to $\mathrm{H}_{2} \mathrm{O}_{2}$, a more stable ROS [31]. There was no significant change in renal SOD activity of SHR compared to WKY rats. Although the mRNA expression of CuZnSOD was slightly lower in the kidney of SHR compared to WKY rats, no statistically significant change in the mRNA expressions of SOD isoenzymes was observed in SHR compared to WKY. Similarly, inspite of slightly reduced mRNA expression of CuZnSOD, no significant difference in the mRNA expressions of CuZnSOD and MnSOD was observed in SHR. Our results showed increased CAT activity in the kidney of control SHR. CAT catalyzes the reduction of $\mathrm{H}_{2} \mathrm{O}_{2}$ to water $\left(\mathrm{H}_{2} \mathrm{O}\right)$ and oxygen $\left(\mathrm{O}_{2}\right)$. Hence, this enzyme protects tissues from highly reactive hydroxyl radical $(\cdot \mathrm{OH})$, derived from $\mathrm{H}_{2} \mathrm{O}_{2}$ [32]. In experimental studies, increased $\mathrm{H}_{2} \mathrm{O}_{2}$ concentration is accompanied by elevated activity of CAT and/or GPx [33, 34]. Therefore, enhanced CAT activity in the kidney of control SHR may be an adaptive response to metabolize increased concentrations of $\mathrm{H}_{2} \mathrm{O}_{2}$. Although both CAT and GPx play a major role in the metabolism of $\mathrm{H}_{2} \mathrm{O}_{2}, \mathrm{GPx}$ is less efficient than CAT because it is easily inhibited in the presence of increased levels of $\mathrm{H}_{2} \mathrm{O}_{2}[35,36]$. Considering that elevated $\mathrm{H}_{2} \mathrm{O}_{2}$ generation is reported in SHR [37], enhanced CAT activity in kidney of control SHR may imply increased $\mathrm{H}_{2} \mathrm{O}_{2}$ production and the insufficiency of GPx to detoxify this substrate. Interestingly, the fold 
change in mRNA expression of CAT in the kidney of SHR did not differ from that of the WKY rats. Discrepancy in CAT activity (reduced activity) and CAT mRNA expression (increased expression) has been reported in brain tissue of rats [38]. The lack of significant change in the activity and mRNA expression of GPx may further suggest that GPx compared to CAT plays a less prominent role in the detoxification of elevated levels of $\mathrm{H}_{2} \mathrm{O}_{2}$. Treatment of SHR with honey significantly reduced CAT activity. This may be due to reduced bodily demand for an enhanced endogenous antioxidant defense (CAT) as a result of honey supplementation. Thus, this confirms that increased CAT activity in the kidney of SHR is induced in response to increased oxidative stress.

Our results indicated that concentrations of MDA, a prominent marker for the assessment of lipid peroxidation $[39,40]$, were significantly elevated in the kidney of control SHR. These data corroborate those of other investigators who reported elevated levels of MDA in the kidney of SHR [41]. The elevated MDA levels in the kidney of control SHR indicate increased lipid peroxidation. In our previous study [12], we reported that the levels of MDA were much lower in the kidney of SHR than of WKY. We did suggest that the reduced MDA contents in SHR might be due to increased CAT activity and enhanced TAS [12]. However, in this study, we found that the MDA levels were elevated in the kidney of SHR in spite of enhanced CAT activity and TAS. The data in the current study suggest that the enhanced CAT activity and TAS in the kidney of SHR are not protective against oxidative damage. Honey supplementation in SHR moderately restored elevated TAS and significantly reduced the levels of MDA, indicative of reduced oxidative damage. The fact that these honey-treated SHR also had less severe hypertension is consistent with other studies that reported increased levels of MDA in hypertension [41, 42].

The data showed an enhanced activity of GST in the kidney of control SHR. GST protects cells or tissues against oxidative stress and damage by detoxifying various toxic substrates, including end products of lipid peroxidation such as MDA and 4-HNE (4-hydroxynonenal), derived from cellular oxidative processes [43]. The increased GST activity may be due to enzyme induction in order to detoxify the elevated levels of MDA and other lipid peroxidative products. This is usually an adaptive or compensatory mechanism to enhance cellular resistance and protect tissues from the deleterious effects of these toxic aldehydes [44]. In contrast to the increased GST activity, the mRNA expressions of GST- $\alpha$ and GST- $\Pi$ in the kidney of control SHR were significantly downregulated. Four classes of GST isoenzymes (GST- $\alpha$, GST- $\mu$, GST- $\Pi$, and GST- $\theta$ ) have been identified [45]. Nevertheless, the mRNA expressions of GST- $\alpha$ and GST- $\Pi$ were investigated because they are the main GST isoenzymes predominantly expressed in rat kidney [46]. A number of compounds, such as xenobiotics, lead as well as ROS are reported to induce activity and expressions of GST isoenzymes [46, 47]. It has been reported that increased GST activity and upregulated GST- $\Pi$ expression correlates with increased oxidative stress and apoptosis in breast cancer [48].
The downregulated mRNA expressions of GST- $\alpha$ and GST$\Pi$ in kidney of SHR corroborate those of other authors who also reported reduced GST mRNA expression in the kidney of SHR [49]. The administration of honey significantly reduced GST activity in SHR similar to that of normotensive WKY rats. This may be due to reduced demand for the induction of renal GST as a result of antioxidant (honey) supplementation.

The data showed that the mRNA expression of Nrf2 was significantly downregulated in the kidney of SHR compared to WKY rats, similar to recently reported findings [50]. Nrf2, an important transcription factor, detects xenobiotics and imbalances in redox status and coordinates the transcription of a variety of cytoprotective genes [51]. Under physiological conditions, Nrf2 remains bound to Keap1 (Kelch-like ECHassociating protein 1) in the cytosol [51]. However, under oxidative or xenobiotic stress, Nrf2 is liberated from its repressor, Keap1, and translocates from the cytoplasm to the nucleus $[51,52]$. It forms heterodimer with small Maf (musculoaponeurotic fibrosarcoma) proteins and binds to the antioxidant response element (ARE) in the promoter region of a range of detoxifying and cytoprotective genes, resulting in their transcription $[51,52]$. The transcription of these genes leads to the induction of different phase II metabolizing, free radical scavenging, and other detoxifying enzymes which swiftly neutralize, detoxify, and eliminate the oxidants or xenobiotics $[51,52]$. The downregulation of Nrf2 mRNA expression paralleled the significant downregulation of mRNA expressions of GST- $\alpha$ and GST- $\Pi$ in the kidney of SHR. Besides, the reduced mRNA expression of GST- $\Pi$ in honey-treated WKY rats may be due to the downregulated expression of $\mathrm{Nrf} 2$ in these rats. A study reported that Nrf2-null mice had markedly reduced expression of several GST isoenzymes [53]. This suggests that the reduced GST mRNA expressions may be a result of reduced or impaired expression of Nrf2 in SHR. Our results are also in agreement with those of Reisman et al. who reported that the mRNA expressions of cytoprotective genes that detoxify electrophiles, such as GST, are more influenced by Nrf2 in keap1-kd mice than those that detoxify reactive oxygen species, such as SOD, CAT, and GPx [54]. In our previous study, CAT activity and TAS were increased, but MDA was reduced in SHR [12]. In this study, in addition to increased CAT activity and TAS, GST activity was also increased while the levels of MDA were elevated. Considering the findings of Reisman et al. [54], we suggest that there may be a progression from oxidative stress to electrophilic stress as the level of oxidative stress increases.

It remains unclear whether reduced mRNA expression of Nrf2 is a consequence of oxidative stress or otherwise. Exposure of rat pulmonary microvascular endothelial cells to low and moderate doses of $\mathrm{H}_{2} \mathrm{O}_{2}$ has been shown to result in the nuclear accumulation of Nrf2, enhanced Nrf2-ARE-binding activity, and upregulated expression of ARE-regulated gene [55]. These authors also reported that, in contrast, cells exposed to $\mathrm{H}_{2} \mathrm{O}_{2}$ at high doses were characterized by $\mathrm{H}_{2} \mathrm{O}_{2}$ concentration-dependent translocation of $\mathrm{Nrf} 2$ from the nucleus to the cytosol, reduced Nrf2-ARE-binding activity, and downregulated 
expression of ARE-mediated gene. The study further revealed that the levels of cellular damage were considerably higher in the cells exposed to $\mathrm{H}_{2} \mathrm{O}_{2}$ at high doses whereas the levels of cellular damage in the cells exposed to $\mathrm{H}_{2} \mathrm{O}_{2}$ at low and moderate doses were similar to those under the normal condition [55]. Similarly, Rojo et al. found that long-term exposure to $\mathrm{H}_{2} \mathrm{O}_{2}$ causes downregulation of Akt, activation of glycogen synthase kinase-3 beta (GSK-3 $\beta$ ), and nuclear translocation of Nrf2 to the cytoplasm, thereby, impairing the antioxidant response of cells [56]. By and large, these findings corroborate ours in which increased ROS/oxidative stress and damage in the kidney of SHR was associated with downregulated expression of Nrf2. These data suggest that low and moderate doses of $\mathrm{H}_{2} \mathrm{O}_{2}$ or perhaps low levels of oxidative stress may induce Nrf2 activity and expression, thereby, protecting cellular organelles against oxidative damage $[12,55]$. On the other hand, high concentrations of $\mathrm{H}_{2} \mathrm{O}_{2}$ or elevated levels of ROS/oxidative stress result in reduced Nrf2 activity and expression, thereby, increasing the susceptibility of cellular components to oxidative damage as a result of reduced/impaired antioxidant response of cells $[55,56]$. The significantly reduced activity of renal CAT in honey-treated SHR suggest reduced $\mathrm{H}_{2} \mathrm{O}_{2}$ concentrations as a result of honey supplementation. This may contribute to increased translocation of $\mathrm{Nrf} 2$ from the cytosol to the nucleus as evidenced by the moderately upregulated expression of Nrf2 in SHR. Hence, these results indicate that antioxidants (free radical scavengers), $\mathrm{H}_{2} \mathrm{O}_{2}$-metabolizing enzymes (CAT and/or GPx) as well as other ROS-scavenging enzymes may elicit a protective effect on Nrf2 and help to maintain/augment physiological functions of Nrf2.

Moreover, despite increased oxidative stress which is a key inducer of Nrf2 [50,51], the kidney of SHR had reduced Nrf2 mRNA expression. This suggests that Nrf2, a potential renoprotective transcription factor, may be impaired or deficient in kidney of SHR, resulting in the inability of SHR to upregulate Nrf2 in response to oxidative or electrophilic insult. Honey administration, while moderately though not significantly upregulating Nrf2 mRNA expression, considerably attenuated activities of antioxidant enzymes and reduced lipid oxidative damage in kidney of SHR similar to the levels in normotensive WKY rats. In view of the moderate upregulation of Nrf2 in honey-treated SHR, one would have expected similar results in honey-treated WKY rats. Surprisingly, our results showed that honey supplementation in normotensive WKY rats was associated with reduced Nrf2 mRNA expressions. The reason remains unclear. However, a study reported a similar finding in Keap1-kd mice [54]. The study showed that Nrf2 mRNA expression was moderately decreased in Keap1-kd mice compared with wild type. It is suggested that this may be due to a plausible negative feedback pathway for Nrf2 mRNA expression as a result of Nrf2 overactivation [54]. Therefore, the reduction of Nrf2 mRNA expression in kidney of honey-treated WKY rats may be a consequence of a negative feedback mechanism arising from increased Nrf2 stimulation and translocation following daily honey supplementation in WKY rats.

In the kidney of normotensive WKY rats, similar to our previous studies $[20,57]$, honey supplementation did not affect most of the renal oxidative stress parameters investigated. Surprisingly, our data revealed that CAT activity was significantly reduced in the honey-supplemented WKY rats compared to control WKY rats. Besides, we found a slight trend (but statistically insignificant) towards reduced MDA levels in honey-treated WKY compared with control WKY rats. These findings are in contrast with what we found in our previous studies which showed that the activity of CAT and the levels of MDA were comparable in the kidney and pancreas of honey-treated Sprague-Dawley (SD) and untreated SD rats $[20,57]$. These discrepancies may arise from differences in rat strains. Similar differences in markers of oxidative stress in SD and WKY rats have also been reported in another study [58]. The reduced CAT activity in WKY rats may be attributed to the downregulated expression of Nrf2 in these rats [54]. Furthermore, there is evidence which suggests an association between oxidative stress and aging process [59], which may provide another possible explanation for this disparity. In all the studies, the age of the $\mathrm{SD}$ and WKY rats before treatment commenced was the same (12-14 weeks old). However, the duration of treatment was 12 weeks in the present study, whereas it was 4 weeks $[20,57]$ or 3 weeks [12] in the previous studies. Moreover, renal production of $\mathrm{H}_{2} \mathrm{O}_{2}$ and urinary excretion of MDA has been reported to be significantly higher in older WKY rats than their young counterparts [60]. Therefore, significantly higher CAT activity and slightly higher levels of MDA in the kidney of control WKY rats compared to honey-treated WKY rats may imply increased $\mathrm{H}_{2} \mathrm{O}_{2}$ generation and the occurrence of perhaps low levels of oxidative stress in normotensive WKY rats.

In summary, the increased activity of CAT and TAS observed in the kidney of SHR in this study and our previous study [12] may represent an adaptive mechanism in response to increased oxidative stress. While in the previous study, this adaptive mechanism appeared to protect against oxidative damage as evidenced by the significantly reduced levels of MDA in kidney of SHR compared to WKY rats [12]. In the present study, the enhanced TAS and CAT activity is not protective against oxidative damage as evident from the significantly elevated levels of MDA in kidney of control SHR compared to control WKY rats. The insufficiency of adaptive or compensatory mechanism to protect against oxidative damage may be due to the longer duration of this study which allowed unrelenting ROS generation, resulting in increased oxidative stress and damage. The elevated levels of ROS (perhaps $\mathrm{H}_{2} \mathrm{O}_{2}$ ) and MDA in SHR may result in induction of CAT and GST activities, respectively. The discrepancies in the results on the gene expression and activity of the antioxidant enzymes are in agreement with previously reported findings which showed that alterations in mRNA expressions of antioxidant enzymes do not necessarily correlate with their protein expressions and/or activities [32, 61-67]. These inconsistencies in the effect of oxidative stress on mRNA expression and antioxidant enzyme protein/activity are attributed to various factors including RNA splicing, increased degradation of the mRNA, protein modifications such as protein turnover and degradation, influence of kinase/phosphatase signal 
transduction pathway on posttranscriptional regulation, differences between transcription and translation, induction of antioxidant enzyme activity/synthesis, and variation in the cellular redox status [32, 61-67]. Our results also corroborate previous findings which showed that Nrf2 plays a more important transcriptional role in the expression of GST than other ROS-scavenging enzymes [53, 54]. This study also showed that elevated blood pressure is associated with increased oxidative damage and downregulated mRNA expressions of Nrf2 in kidney of SHR. Our data indicate that the attenuation of antioxidant enzymes (and/or perhaps scavenging of $\mathrm{H}_{2} \mathrm{O}_{2} / \mathrm{ROS}$ ) as a result of honey supplementation may contribute to the moderately upregulated expression of Nrf2 in the kidney of SHR. The reduction of elevated blood pressure, protection of kidney against oxidative damage, and the attenuation of GST and CAT activities as a result of honey supplementation corroborate the beneficial effects of tualang honey on hypertension and oxidative stress in SHR.

\section{Materials and Methods}

\subsection{Materials}

4.1.1. Chemicals. Thiobarbituric acid (TBA), GSH, and GSSG were purchased from Sigma-Aldrich (St. Louis, MO, USA). GSH : GSSG assay kit was purchased from Calbiochem (CA, USA). SOD and GPx assay kits were purchased from Cayman (MI, USA). Bio-Rad protein assay kit was purchased from Bio-Rad (USA). RNA Later solution and RNeasy Mini Kit were purchased from Qiagen (Hilden, Germany). cDNA synthesis kit was purchased from Bioline (Randolph, USA). The primers were purchased from 1st Base (Singapore). FastStart Universal SYBR Green Master (Rox) was purchased from Roche Dignostics (IN, USA). All other chemicals used were of analytical grade obtained from commercial sources.

4.1.2. Animals. All experimental protocols were approved by the Animal Ethics Committee of Universiti Sains Malaysia, Malaysia [USM/Animal Ethics Approval/2009/(46) (145)]. Male spontaneously hypertensive (SHR) and Wistar-Kyoto (WKY) rats, 12-14 weeks old, were obtained from the Laboratory Animal Research Unit of Universiti Sains Malaysia, Health Campus, Kelantan, Malaysia. The rats were acclimatized to the animal room conditions for at least one week prior to the experiment. Handling of animals was in compliance with the Institutional Guidelines for the Care and Use of Animals for Scientific Purposes. The animals were caged individually in polypropylene cages in a well-ventilated animal room with a 12 -h dark $/ 12 \mathrm{~h}$-light cycle (lights on 7.00 a.m., lights off 7.00 p.m.) and controlled temperature $\left(25 \pm 2^{\circ} \mathrm{C}\right)$. All the rats had free access to standard diet and drinking water ad libitum.

4.1.3. Tualang Honey. Tualang honey (AgroMas, Malaysia) was supplied by Federal Agricultural Marketing Authority (FAMA), Kedah, Malaysia. The honey has the following composition: total reducing sugar $(67.5 \%)$ [fructose $(29.6 \%)$, glucose $(30.0 \%)$, maltose $(7.9 \%)$, fructose/glucose ratio
(0.99)], sucrose $(0.6 \%)$, and water $(20.0 \%)$. The honey was diluted with distilled water $(1: 1)$ before it was administered. The dose $(1.0 \mathrm{~g} / \mathrm{kg})$ was chosen based on our previous study [21].

\subsection{Methods}

4.2.1. Treatment. The WKY and SHR rats were randomly divided into four groups consisting of six to seven rats. The animals were treated via oral gavage once daily for 12 weeks as follows:

Group 1: WKY rats received distilled water $(0.5 \mathrm{~mL})$.

Group 2: WKY rats received tualang honey $(1.0 \mathrm{~g} / \mathrm{kg}$ body weight).

Group 3: SHR were administered distilled water $(0.5 \mathrm{~mL})$.

Group 4: SHR were administered tualang honey ( $1.0 \mathrm{~g} / \mathrm{kg}$ body weight).

4.2.2. Measurement of Systolic Blood Pressure (SBP). SBP was measured in conscious rats by a tail-cuff plethysmographic noninvasive method (Model 179, Life Science, USA) every two weeks as previously described [12]. Briefly, conscious rats were placed on a heated pad in a temperature-controlled space. They were allowed to calm for about 15 minutes with the tail placed inside a tail cuff. The cuff was inflated and released several times to condition the animal to the procedure. Four consecutive measurements were then taken by a rat-tail blood pressure monitor, recorded by a student oscillograph (Harvard Apparatus Inc., MA, USA). Each SBP was obtained by averaging 4 individual readings.

4.2.3. Processing of Tissues. After 12 weeks of treatment, the animals were sacrificed. The left kidney was rapidly excised, washed in ice-cold phosphate-buffered saline, blotted and immediately stored at $-80^{\circ} \mathrm{C}$ until processing. The frozen left kidney was allowed to thaw on ice. Homogenates $(10 \%$ $\mathrm{w} / \mathrm{v})$ were prepared in $\mathrm{Tris}-\mathrm{HCl}(0.1 \mathrm{M}, \mathrm{pH} 7.4)$ with the aid of a tissue grinder fitted with a motor-driven ground glass pestle (Glas-Col, USA) at 900 revolution per minute (rpm). Homogenates were centrifuged at $1000 \times \mathrm{g}$ for 10 minutes at $4^{\circ} \mathrm{C}$ in a refrigerated centrifuge to remove tissue debris without precipitation of plasma membrane fragments. The resulting supernatant was used for the assay of total protein, activities of antioxidant enzymes, and markers of oxidative stress.

4.2.4. Lipid Peroxidation (LPO) Assay. LPO was determined as the concentration of MDA according to the method of Ohkawa et al. [68]. Briefly, $100 \mu \mathrm{L}$ of kidney homogenates $(10 \% \mathrm{w} / \mathrm{v})$ or MDA standards were pipetted into test tubes containing $1.5 \mathrm{~mL}$ of $20 \%(\mathrm{v} / \mathrm{v})$ glacial acetic acid ( $\mathrm{pH} 3.5)$, $200 \mu \mathrm{L}$ of $8.1 \%(\mathrm{w} / \mathrm{v})$ sodium dodecyl sulphate (SDS), $1.5 \mathrm{~mL}$ of $0.8 \%(\mathrm{w} / \mathrm{v}) \mathrm{TBA}$, and $700 \mu \mathrm{L}$ of distilled water. The test tubes were incubated at $95^{\circ} \mathrm{C}$ for 60 minutes with a marble on top of each test tube. After incubation, the test tubes were cooled and then centrifuged at $3,000 \times \mathrm{g}$ for 10 minutes. The 
amount of MDA formed was measured spectrophotometrically at $532 \mathrm{~nm}$. 1,1,3,3-Tetraethoxypropane (TEP), a form of MDA, was used as standard in this assay. MDA concentration was expressed as nmol of MDA per mg protein.

4.2.5. Reduced, Oxidized, and Total Glutathione Assays. Total glutathione and GSSG were estimated using GSH:GSSG ratio assay kit (Calbiochem, CA, USA) according to the manufacturer's instructions. GSH was then calculated. Briefly, the kidney homogenates $(10 \% \mathrm{w} / \mathrm{v})$ were deproteinized in metaphosphoric acid (5\% w/v), centrifuged, and the supernatants were used for the estimation of glutathione. For GSSG assay, the kidney homogenates were immediately mixed with the thiol-scavenging reagent, 1-methy2-vinylpyridinium trifluoromethanesulfonate to derivatize GSH. Samples were mixed sequentially with the chromogen 5,5'-dithiobis-2-nitrobenzoic acid, glutathione reductase, and NADPH. The absorbance of each sample was recorded at $412 \mathrm{~nm}$, and the reaction rate was determined. A standard curve was constructed using a known quantity of GSH standards. GSH and GSSG concentrations were calculated by linear regression against the standard curve. GSH/GSSG ratio was calculated using the formula [ratio = (GSH - 2GSSG)/GSSG]. GSH and GSSG concentrations were expressed as $\mathrm{nM}$ of glutathione per $\mathrm{mg}$ protein.

4.2.6. Total Antioxidant Status (TAS) Assay. TAS was measured according to the method of Koracevic et al. [69]. Briefly, $10 \mu \mathrm{L}$ of kidney homogenate $(10 \% \mathrm{w} / \mathrm{v})$ was pipetted in a test tube containing $0.49 \mathrm{~mL}$ of $100 \mathrm{mM}$ sodium phosphate buffer $(100 \mathrm{mM})$. This was followed by the addition of $0.5 \mathrm{~mL}$ of $10 \mathrm{mM}$ sodium benzoate $(10 \mathrm{mM})$ solution, $0.2 \mathrm{~mL}$ of Fe-EDTA mixture prepared from $2 \mathrm{mM}$ EDTA solution and $2 \mathrm{mM} \mathrm{Fe}\left(\mathrm{NH}_{4}\right)_{2}\left(\mathrm{SO}_{4}\right)_{2}$ solution, and $0.2 \mathrm{~mL}$ of $\mathrm{H}_{2} \mathrm{O}_{2}(10 \mathrm{mM})$ solution. Each sample had its own control (blank) in which $1 \mathrm{~mL}$ of acetic acid (20\%) was added followed by the addition of $0.2 \mathrm{~mL}$ of Fe-EDTA mixture and $0.2 \mathrm{~mL}$ of $\mathrm{H}_{2} \mathrm{O}_{2}(10 \mathrm{mM})$. Negative control (with phosphate buffer instead of the kidney homogenate) containing similar reagents as in sample test tubes was also prepared. After the addition of these reagents, the test tubes were vortexed and incubated at $37^{\circ} \mathrm{C}$ for 60 minutes. This was followed by the addition of $1 \mathrm{~mL}$ of acetic acid (20\%) (sample test tubes only) and TBA $(0.8 \%$ $\mathrm{w} / \mathrm{v})$. The reaction tubes were incubated at $100^{\circ} \mathrm{C}$ for 10 minutes. After cooling to room temperature, the absorbance of the mixture was measured spectrophotometrically at $532 \mathrm{~nm}$ against distilled water. TAS levels in the kidney homogenates were calculated using uric acid as standard. TAS was expressed as nmol uric acid equivalent per mg protein.

4.2.7. Superoxide Dismutase (SOD) Assay. SOD activity was measured using Cayman (MI, USA) assay kit according to the manufacturer's instructions. This assay kit utilizes a tetrazolium salt for the detection of superoxide radicals generated by xanthine oxidase and hypoxanthine. One unit of SOD is defined as the amount of enzyme needed to exhibit $50 \%$ dismutation of $\mathrm{O}_{2}{ }^{\bullet-}$. The SOD assay measures all the three types of $\mathrm{SOD}(\mathrm{Cu} / \mathrm{Zn}, \mathrm{Mn}$, and FeSOD).

4.2.8. Glutathione Peroxidase (GPx) Assay. GPx activity was measured using Cayman (MI, USA) assay kit according to manufacturers' instructions. This kit measures GPx activity indirectly by a coupled reaction with GR. GSSG, produced upon the reduction of hydroperoxide by $\mathrm{GPx}$, is recycled to its reduced state by GR and NADPH. The oxidation of $\mathrm{NADPH}$ is accompanied by a decrease in absorbance at $340 \mathrm{~nm}$. One unit of GPx is defined as the amount of enzyme that catalyzes the oxidation of $1 \mathrm{nmol}$ of NADPH per minute at $25^{\circ} \mathrm{C}$.

4.2.9. Catalase (CAT) Assay. CAT activity was measured according to the method of Goth [70]. Briefly, this assay involves the incubation of sample test tube containing $0.5 \mathrm{~mL}$ of hydrogen peroxide $(65 \mathrm{mM})$ and $0.1 \mathrm{~mL}$ of kidney homogenate $(10 \% \mathrm{w} / \mathrm{v})$. After incubation at $37^{\circ} \mathrm{C}$ for 60 seconds, the enzymatic reaction was stopped by the addition of $0.5 \mathrm{~mL}$ of ammonium molybdate $(32.4 \mathrm{mM})$ solution. The yellow complex of ammonium molybdate and hydrogen peroxide was then measured spectrophotometrically at $405 \mathrm{~nm}$. One unit of CAT is defined as the amount of enzyme that catalyzes the decomposition of $1 \mu \mathrm{mol}$ of hydrogen peroxide per minute.

4.2.10. Glutathione Reductase (GR) Assay. GR activity was assayed according to the method of Goldberg and Spooner [71]. Briefly, $1 \mathrm{~mL}$ of $2.728 \mathrm{mM}$ GSSG solution and $40 \mu \mathrm{L}$ of kidney homogenate $(10 \% \mathrm{w} / \mathrm{v})$ were incubated for 5 minutes at $37^{\circ} \mathrm{C}$. After incubation, the reaction was initiated by the addition of $200 \mu \mathrm{L}$ of $1.054 \mathrm{mM}$ NADPH solution. The decrease in absorbance was measured at $340 \mathrm{~nm}$ using spectrophotometer and recorded every 30 seconds over a period of 5 minutes. GR activity was expressed as unit per mg protein based on molar extinction coefficient of $6.22 \times$ $10^{3} \mathrm{~L} / \mathrm{mol} / \mathrm{cm}$. One unit of GR is defined as the amount of enzyme that catalyzes the oxidation of $1 \mathrm{nmol}$ of NADPH per minute.

4.2.11. Glutathione-S-Transferase (GST) Assay. GST activity was assayed according to the method of Habig et al. [72]. Briefly, $2 \mathrm{~mL}$ of $0.3 \mathrm{M}$ potassium phosphate buffer ( $\mathrm{pH}$ 6.35), $75 \mu \mathrm{L}$ of $30 \mathrm{mM}$ CDNB solution, $725 \mu \mathrm{L}$ of distilled water, and $0.1 \mathrm{~mL}$ of kidney homogenate $(10 \% \mathrm{w} / \mathrm{v})$ were pipetted into a test tube. The test tube was vortexed and incubated at $37^{\circ} \mathrm{C}$ for 10 minutes. After incubation, the reaction was initiated by the addition of $100 \mu \mathrm{L}$ of $30 \mathrm{mM}$-reduced glutathione solution. The decrease in absorbance was measured spectrophotometrically at $340 \mathrm{~nm}$ and recorded every 30 seconds for 4 minutes. GST activity was calculated as unit per mg protein based on a molar extinction coefficient of $9.6 \times 10^{3} \mathrm{~L} / \mathrm{mol} / \mathrm{cm}$. One unit of GST is defined as the amount of enzyme that catalyzes the conjugation of $1 \mathrm{nmol}$ of GSHCDNB per minute. 
TABLE 3: Gene-specific primers for all the genes investigated.

\begin{tabular}{|c|c|c|c|c|}
\hline Gene & Genbank accession no & Primer sequence & PCR product (bp) & Annealing temp. $\left({ }^{\circ} \mathrm{C}\right)$ \\
\hline \multirow{2}{*}{ CuZnSOD } & \multirow{2}{*}{ NM017050 } & F: 5'-GCAGAAGGCAAGCGGTGAAC-3' & \multirow{2}{*}{447} & \multirow{2}{*}{62} \\
\hline & & R: 5' -TAGCAGGACAGCAGATGAGT-3' & & \\
\hline \multirow{2}{*}{ MnSOD } & \multirow{2}{*}{ NM017051 } & F: 5'-CTGAGGAGAGCAGCGGTCGT-3' & \multirow{2}{*}{258} & \multirow{2}{*}{68} \\
\hline & & R: 5'-CTTGGCCAGCGCCTCGTGGT-3' & & \\
\hline \multirow{2}{*}{ CAT } & \multirow{2}{*}{ BC081853 } & F: 5'-GCGAATGGAGAGGCAGTGTAC-3' & \multirow{2}{*}{652} & \multirow{2}{*}{67} \\
\hline & & R: 5'-GAGTGACGTTGTCTTCATTAGCACTG-3' & & \\
\hline \multirow{2}{*}{ GPx1 } & \multirow{2}{*}{ M21210 } & F: 5'-CTCTCCGCGGTGGCACAGT-3' & \multirow{2}{*}{290} & \multirow{2}{*}{57} \\
\hline & & R: 5'-CCACCACCGGGTCGGACATAC-3' & & \\
\hline \multirow{2}{*}{ GST $-\pi$} & \multirow{2}{*}{ L29427 } & F: 5'-GGAGGAGGTGGTTACCATAGATGTC-3' & \multirow{2}{*}{389} & \multirow{2}{*}{68} \\
\hline & & R: 5'-GCAGGTCCAGCAAGTTGTAATCTGC-3' & & \\
\hline \multirow{2}{*}{ GST- $\alpha 1 / 2$} & \multirow{2}{*}{ AF111160 } & F: 5'-CCACCTGCTGGAACTTCTCCTCTAT-3' & \multirow{2}{*}{99} & \multirow{2}{*}{68} \\
\hline & & R: 5'-AGGCTGCTGATTCTGCTCTTGAAGG-3' & & \\
\hline \multirow{2}{*}{ Nrf2 } & \multirow{2}{*}{ NM031789 } & F: 5'-CCATTTACGGAGACCCAC-3' & \multirow{2}{*}{448} & \multirow{2}{*}{55} \\
\hline & & R: 5' -TGAGCGGCAACTTTATTC-3' & & \\
\hline \multirow{2}{*}{$\beta$-actin } & \multirow{2}{*}{ NM031144 } & F: 5' -CTGACCGAGCGTGGCTAC-3' & \multirow{2}{*}{505} & \multirow{2}{*}{58} \\
\hline & & R: 5'-CCTGCTTGCTGATCCACA-3' & & \\
\hline
\end{tabular}

4.2.12. Protein Assay. Protein concentration was estimated using Bio-Rad protein assay kit based on the method of Bradford [73]. A standard curve was generated using bovine serum albumin as standard.

4.2.13. Real-Time Reverse Transcription-Polymerase Chain Reaction (RT-PCR) Assay. The excised kidneys were stored in RNA Later solution (Qiagen, Hilden, Germany) overnight at $4^{\circ} \mathrm{C}$ before transferred to $-80^{\circ} \mathrm{C}$ until the isolation of RNA. Total RNA was isolated using RNeasy Mini Kit (Qiagen, Hilden, Germany) according to the manufacturer's instructions. RNA was eluted in $40 \mu \mathrm{L}$ of RNase-free water. The concentration of isolated RNA was quantified at $260 \mathrm{~nm}$ using Infinite 200 NanoQuant (Tecan, USA). The ratio of the readings of absorbance at $260 \mathrm{~nm}$ and $280 \mathrm{~nm}(A 260 / A 280)$, ranging from 1.95 to 2.10 , was used as an estimate of the purity of isolated RNA. The integrity of extracted RNA was checked by $1 \%$ agarose gel electrophoresis stained with ethidium bromide. Single-strand cDNA was synthesized using cDNA synthesis kit (Bioline, Randolph, USA) according to the manufacturer's instructions. Briefly, single-strand cDNA synthesis was carried out by incubating a PCR tube containing $1 \mu \mathrm{g}$ of the isolated RNA, $1 \mathrm{uL}$ of oligo $(\mathrm{dT})_{18}$, and $10 \mathrm{mM}$ of $\mathrm{dNTP}$ at $65^{\circ} \mathrm{C}$ for 10 minutes. The tube was chilled on ice for 2 minutes. $4 \mathrm{uL}$ of $5 \mathrm{x}$ RT buffer, $1 \mathrm{uL}$ of RNase inhibitor, $0.25 \mathrm{uL}$ of reverse transcriptase, and $4.75 \mathrm{uL}$ of DEPC-treated water were added to the primed RNA. The reaction mixture was incubated at $37^{\circ} \mathrm{C}$ for 15 minutes, followed by incubation at $42^{\circ} \mathrm{C}$ for another 15 minutes, and finally incubated at $45^{\circ} \mathrm{C}$ for 30 minutes. The reaction was terminated by incubating at $70^{\circ} \mathrm{C}$ for 15 minutes followed by cooling on ice.

A number of tests were performed in order to ensure that the primers were specific and efficient. Different concentrations of primers were analyzed by performing positive and negative control PCR at several annealing temperatures, ranging from $54^{\circ} \mathrm{C}$ to $68^{\circ} \mathrm{C}$. The PCR product was subjected to $1.5 \%$ agarose gel electrophoresis to detect primer specificity by revealing the presence or absence of primer dimers. The reverse transcription polymerase chain reaction (RTPCR) quantification was performed using Mx3000P realtime PCR instrument (Stratagene, TX, USA). Each PCR reaction contained $2 \mu \mathrm{L}$ of cDNA, $12.5 \mu \mathrm{L}$ of $2 \times$ FastStart Universal SYBR Green Master (Rox) (Roche Dignostics, IN, USA), $0.5 \mu \mathrm{L}$ of $300 \mathrm{nM}$ of the forward, and reverse primers and $14.5 \mu \mathrm{L}$ of PCR-grade water. For each set of primers, a control PCR mixture without template cDNA was subjected to PCR in parallel to exclude potential DNA carry-over during sample preparation. The reactions were performed on a 96-well plate, and a PCR amplification protocol was followed. Amplification was performed for 35 cycles of denaturation at $95^{\circ} \mathrm{C}$ for 1 minute, annealing at $55^{\circ} \mathrm{C}-68^{\circ} \mathrm{C}$ (specific for each gene) for 1 minute, and extension at $72^{\circ} \mathrm{C}$ for 1 minute, followed by a melting curve phase. Prior to the melting curve phase, the $\mathrm{PCR}$ reaction mixture was incubated at $95^{\circ} \mathrm{C}$ for $1 \mathrm{~min}$ and then ramped down to $55^{\circ} \mathrm{C}$ for $30 \mathrm{sec}$. The melting curve analysis was then carried out by increasing the temperature from $55^{\circ} \mathrm{C}$ to $95^{\circ} \mathrm{C}$ which occurred at the instrument default rate of $0.2^{\circ} \mathrm{C} / \mathrm{sec}$. The instrument then collected the fluorescence data on the $55-95^{\circ} \mathrm{C}$ ramp persistently for about 15 minutes. The postamplification melting curve was to confirm the presence of a single PCR product. The quality of the PCR product was analyzed by $1.5 \%$ agarose gel electrophoresis. Primer sequences used in the RT-PCR experiments were based on the published sequences and synthesized by First Base (Singapore) according to the cDNA sequences obtained from the GenBankTM database for rat. The quantitation of the each target gene in all the samples was normalized to $\beta$-actin expression. The primer sequences for $\beta$-actin (as a housekeeping gene), CuZnSOD, CAT and GPx [74], MnSOD [75], GST- $\alpha$ [76], GST-П [77], and Nrf2 [78] are shown in Table 3. Fold changes in target gene expression were calculated using the $2^{-\Delta \Delta \mathrm{CT}}$ method [79]. For the use 
of $2^{-\triangle \Delta C T}$ method, serial dilutions of cDNA were performed to validate the amplification efficiencies of each target gene and housekeeping gene. The mean $\mathrm{C}_{\mathrm{T}}$ was calculated for the target gene and housekeeping gene. The difference between the $\mathrm{C}_{\mathrm{T}}$ target gene and $\mathrm{C}_{\mathrm{T}} \beta$-actin was used as $\Delta \mathrm{C}_{\mathrm{T}}$. The normotensive WKY control group served as the calibrator. The mRNA expression levels of each group of rats were presented as fold changes relative to the mRNA expression levels of the WKY control rats.

4.2.14. Statistical Analysis. Statistical analysis was carried out using SPSS 18.0.1. Data were analyzed using independent sample $t$-test to identify significance of difference between WKY and SHR. Repeated measures ANOVA was used to analyze and compare systolic blood pressure and body weight over the time course. Data are expressed as mean \pm SEM. For the analysis of antioxidant enzyme activities and oxidative stress markers, each group consisted of six to seven rats. For the analysis of mRNA expressions of antioxidant enzymes and Nrf2, each group consisted of four to five rats.

\section{Conclusions}

These results indicate that cells or tissues may augment components of the antioxidant defense system in order to increase cellular resistance and protect against the deleterious effects of oxidative stress. However, this adaptive response may not always be protective against oxidative damage. Findings from this study also indicate that expression of $\mathrm{Nrf2}$, a potential renoprotective transcription factor, is markedly reduced or impaired in the kidney of SHR. Besides, our results reveal that the induction of antioxidant enzymes, perhaps as a compensatory mechanism, may occur in spite of impaired or reduced mRNA expression of Nrf2. The administration of honey protects the kidney against oxidative damage and attenuates oxidative stress-induced antioxidant defenses in SHR. These honey-treated SHR also exhibit reduced SBP. In conclusion, honey supplementation elicits antihypertensive effect via amelioration of oxidative stress in kidney of SHR. Additional studies in the future may help to establish a linkage of hypertension to downregulated activity and expression of Nrf2 or vice versa in SHR and/or human hypertension. With our results, we anticipate a renewed interest in studies that investigate how and to what extent this transcription factor; Nrf2 may interact with other mechanisms to cause or exacerbate hypertension.

\section{Acknowledgments}

This work was supported by a Grant (1001/PPSP/81202020) from Universiti Sains Malaysia (USM). The first author is thankful to USM for the award of Fellowship. We acknowledge Dr. Teguh Haryo Sasongko, Ms. Fatemeh Hayati, Mr. Arifin Harun, and Mr. Koh Chun Haw for their assistance in the laboratory procedures. We also express our appreciation to Federal Agricultural Marketing Authority (FAMA), Kedah, Malaysia for providing tualang honey.

\section{References}

[1] N. Poulter and Ritchie, "Global risk of cardiovascular disease," Heart, vol. 89, no. 2, pp. 2-5, 2003.

[2] World Health Organization, The World Health Report 2002. Reducing Risks, Promoting Healthy Life, WHO, Geneva, Switzerland, 2002.

[3] P. M. Kearney, M. Whelton, K. Reynolds, P. Muntner, P. K. Whelton, and J. He, "Global burden of hypertension: analysis of worldwide data," The Lancet, vol. 365, no. 9455, pp. 217223, 2005.

[4] A. V. Chobanian, G. L. Bakris, H. R. Black et al., "Seventh report of the joint national committee on prevention, detection, evaluation, and treatment of high blood pressure," Hypertension, vol. 42, no. 6, pp. 1206-1252, 2003.

[5] R. Rodrigo, J. González, and F. Paoletto, "The role of oxidative stress in the pathophysiology of hypertension," Hypertension Research, vol. 34, no. 4, pp. 431-440, 2011.

[6] V. Ostrow, S. Wu, A. Aguilar, R. Bonner, E. Suarez, and F. De Luca, "Association between oxidative stress and masked hypertension in a multi-ethnic population of obese children and adolescents," Journal of Pediatrics, vol. 158, pp. 628-633, 2010.

[7] Y. Hirooka, "Oxidative stress in the cardiovascular center has a pivotal role in the sympathetic activation in hypertension," Hypertension Research, vol. 34, no. 4, pp. 407-412, 2011.

[8] C. Fanelli and R. Zatz, "Linking oxidative stress, the reninangiotensin system, and hypertension," Hypertension, vol. 57, no. 3, pp. 373-374, 2011.

[9] A. A. Banday and M. F. Lokhandwala, "Oxidative stress causes renal angiotensin II Type 1 receptor upregulation, $\mathrm{Na}+\mathrm{H}+$ exchanger 3 overstimulation, and hypertension," Hypertension, vol. 57, no. 3, pp. 452-459, 2011.

[10] S. Shull, N. H. Heintz, M. Periasamy et al., "Differential regulation of antioxidant enzymes in response to oxidants," The Journal of Biological Chemistry, vol. 266, no. 36, pp. 2439824403, 1991.

[11] E. Röhrdanz and R. Kahl, "Alterations of antioxidant enzyme expression in response to hydrogen peroxide," Free Radical Biology and Medicine, vol. 24, no. 1, pp. 27-38, 1998.

[12] O. O. Erejuwa, S. A. Sulaiman, M. S. A. Wahab, K. N. S. Sirajudeen, M. S. M. Salleh, and S. Gurtu, "Differential responses to blood pressure and oxidative stress in streptozotocin-induced diabetic wistar-kyoto rats and spontaneously hypertensive rats: effects of antioxidant (Honey) treatment," International Journal of Molecular Sciences, vol. 12, no. 3, pp. 1888-1907, 2011.

[13] M. C. Houston, "The role of cellular micronutrient analysis, nutraceuticals, vitamins, antioxidants and minerals in the prevention and treatment of hypertension and cardiovascular disease," Therapeutic Advances in Cardiovascular Disease, vol. 4, no. 3, pp. 165-183, 2010.

[14] T. J. Kizhakekuttu and M. E. Widlansky, "Natural antioxidants and hypertension: promise and challenges," Cardiovascular Therapeutics, vol. 28, no. 4, pp. e20-e32, 2010.

[15] S. Bogdanov, T. Jurendic, R. Sieber, and P. Gallmann, "Honey for nutrition and health: a review," Journal of the American College of Nutrition, vol. 27, no. 6, pp. 677-689, 2008.

[16] H. T. Tan, R. A. Rahman, S. H. Gan et al., "The antibacterial properties of Malaysian tualang honey against wound and enteric microorganisms in comparison to manuka honey," BMC Complementary and Alternative Medicine, vol. 9, article 34, 2009. 
[17] A. A. Ghashm, N. H. Othman, M. N. Khattak, N. M. Ismail, and R. Saini, "Antiproliferative effect of Tualang honey on oral squamous cell carcinoma and osteosarcoma cell lines," BMC Complementary and Alternative Medicine, vol. 10, article 49, 2010.

[18] X. H. Wang, L. Andrae, and N. J. Engeseth, "Antimutagenic effect of various honeys and sugars against Trp-p-1," Journal of Agricultural and Food Chemistry, vol. 50, no. 23, pp. 69236928, 2002.

[19] N. S. Al-Waili, K. Y. Saloom, T. N. Al-Waili et al., "Influence of various diet regimens on deterioration of hepatic function and hematological parameters following carbon tetrachloride: a potential protective role of natural honey," Natural Product Research, vol. 20, no. 13, pp. 1258-1264, 2006.

[20] O. O. Erejuwa, S. A. Sulaiman, M. S. Wahab, K. N. S. Sirajudeen, M. S. M. D. Salleh, and S. Gurtu, "Antioxidant protection of Malaysian tualang honey in pancreas of normal and streptozotocin-induced diabetic rats," Annales d'Endocrinologie, vol. 71, no. 4, pp. 291-296, 2010.

[21] O. O. Erejuwa, S. Gurtu, S. A. Sulaiman, M. S. A. Wahab, K. N. S. Sirajudeen, and M. S. M. Salleh, "Hypoglycemic and antioxidant effects of honey supplementation in streptozotocininduced diabetic rats," International Journal for Vitamin and Nutrition Research, vol. 80, no. 1, pp. 74-82, 2010.

[22] R. L. Rodgers, "Depressor effect of diabetes in the spontaneously hypertensive rat: associated changes in heart performance," Canadian Journal of Physiology and Pharmacology, vol. 64, no. 9, pp. 1177-1184, 1986.

[23] D. Susic, A. K. Mandal, D. J. Jovovic, G. Radujkovic, and D. Kentera, "Streptozotocin-induced diabetes mellitus lowers blood pressure in spontaneously hypertensive rat," Clinical and Experimental Hypertension-Part A, vol. 12, no. 6, pp. 1021-1035, 1990.

[24] A. J. Davidoff, F. M. Pinault, and R. L. Rodgers, "Ventricular relaxation of diabetic spontaneously hypertensive rat," Hypertension, vol. 15, no. 6, pp. 643-651, 1990.

[25] R. M. Touyz and E. L. Schiffrin, "Reactive oxygen species in vascular biology: implications in hypertension," Histochemistry and Cell Biology, vol. 122, no. 4, pp. 339-352, 2004.

[26] J. Z. Xu, Y. Zhang, S. N. Wu, W. Q. Niu, D. L. Zhu, and P. J. Gao, "Impaired endothelial function in hypertensive patients with target organ damage," Journal of Human Hypertension, vol. 23, no. 11, pp. 751-757, 2009.

[27] C. Tsioufis, A. Kordalis, D. Flessas et al., "Pathophysiology of resistant hypertension: the role of sympathetic nervous system," International Journal of Hypertension, vol. 2011, Article ID 642416, 7 pages, 2011.

[28] H. Kobori, M. Nangaku, L. G. Navar, and A. Nishiyama, "The intrarenal renin-angiotensin system: from physiology to the pathobiology of hypertension and kidney disease," Pharmacological Reviews, vol. 59, no. 3, pp. 251-287, 2007.

[29] F. A. Delano and G. W. Schmid-Schönbein, "Proteinase activity and receptor cleavage: mechanism for insulin resistance in the spontaneously hypertensive rat," Hypertension, vol. 52, no. 2, pp. 415-423, 2008.

[30] J. R. Sowers, "Insulin resistance and hypertension," American Journal of Physiology, vol. 286, no. 5, pp. H1597-H1602, 2004.

[31] I. Fridovich, "Superoxide anion radical (O2/-•), superoxide dismutases, and related matters," The Journal of Biological Chemistry, vol. 272, no. 30, pp. 18515-18517, 1997.

[32] F. Haber and J. Weiss, "The catalytic decomposition of hydrogen peroxide by iron salts," Proceedings of the Royal Society, vol. 147, pp. 332-351, 1934.
[33] M. Tiedge, S. Lortz, R. Munday, and S. Lenzen, "Protection against the co-operative toxicity of nitric oxide and oxygen free radicals by overexpression of antioxidant enzymes in bioengineered insulin-producing RINm5F cells," Diabetologia, vol. 42, no. 7, pp. 849-855, 1999.

[34] D. R. Crawford and K. J. A. Davies, "Adaptive response and oxidative stress," Environmental Health Perspectives, vol. 102, no. 10, pp. 25-28, 1994.

[35] G. F. Gaetani, S. Galiano, L. Canepa, A. M. Ferraris, and H. N. Kirkman, "Catalase and glutathione peroxidase are equally active in detoxification of hydrogen peroxide in human erythrocytes," Blood, vol. 73, no. 1, pp. 334-339, 1989.

[36] Z. Spolarics and J. X. I. Wu, "Role of glutathione and catalase in $\mathrm{H} 2 \mathrm{O} 2$ detoxification in LPS- activated hepatic endothelial and Kupffer cells," American Journal of Physiology, vol. 273, no. 6, pp. G1304-G1311, 1997.

[37] P. Cao, O. Ito, Q. Guo et al., "Endogenous hydrogen peroxide up-regulates the expression of nitric oxide synthase in the kidney of SHR," Journal of Hypertension, vol. 29, no. 6, pp. 1167-1174, 2011.

[38] S. Bhanja and G. B. N. Chainy, "PTU-induced hypothyroidism modulates antioxidant defence status in the developing cerebellum," International Journal of Developmental Neuroscience, vol. 28, no. 3, pp. 251-262, 2010.

[39] H. Esterbauer, R. J. Schaur, and H. Zollner, "Chemistry and Biochemistry of 4-hydroxynonenal, malonaldehyde and related aldehydes," Free Radical Biology and Medicine, vol. 11, no. 1, pp. 81-128, 1991.

[40] J. W. Phillis, "A "radical" view of cerebral ischemic injury," Progress in Neurobiology, vol. 42, no. 4, pp. 441-448, 1994.

[41] X. Hou, Y. H. Shen, C. Li et al., "PPAR $\alpha$ agonist fenofibrate protects the kidney from hypertensive injury in spontaneously hypertensive rats via inhibition of oxidative stress and MAPK activity," Biochemical and Biophysical Research Communications, vol. 394, no. 3, pp. 653-659, 2010.

[42] J. Redón, M. R. Oliva, C. Tormos et al., "Antioxidant activities and oxidative stress byproducts in human hypertension," Hypertension, vol. 41, no. 5, pp. 1096-1101, 2003.

[43] R. Sharma, Y. Yang, A. Sharma, S. Awasthi, and Y. C. Awasthi, "Antioxidant role of glutathione S-transferases: protection against oxidant toxicity and regulation of stress-mediated apoptosis," Antioxidants and Redox Signaling, vol. 6, no. 2, pp. 289-300, 2004.

[44] J. D. Hayes and R. C. Strange, "Potential contribution of the glutathione S-transferase supergene family to resistance to oxidative stress," Free Radical Research, vol. 22, no. 3, pp. 193207, 1995.

[45] B. Mannervik, "The isoenzymes of glutathione transferase," Advances in Enzymology and Related Areas of Molecular Biology, vol. 57, pp. 357-417, 1985.

[46] M. Derbel, T. Igarashi, and T. Satoh, "Differential induction of glutathione S-transferase subunits by phenobarbital, 3methylcholanthrene and ethoxyquin in rat liver and kidney," Biochimica et Biophysica Acta, vol. 1158, no. 2, pp. 175-180, 1993.

[47] R. Pinkus, L. M. Weiner, and V. Daniel, "Role of oxidants and antioxidants in the induction of AP-1, NF- $\kappa \mathrm{B}$, and glutathione S-transferase gene expression," The Journal of Biological Chemistry, vol. 271, no. 23, pp. 13422-13429, 1996.

[48] J. Huang, P. H. Tan, B. K. Tan, and B. H. Bay, "GST-pi expression correlates with oxidative stress and apoptosis in breast cancer," Oncology Reports, vol. 12, no. 4, pp. 921-925, 2004. 
[49] J. R. Koo, K. H. Liang, and N. D. Vaziri, "Microarray analysis of altered gene expression in kidneys of adult spontaneously hypertensive rats," Journal of Applied Research, vol. 4, no. 1, pp. 111-126, 2004.

[50] H. J. Kim and N. D. Vaziri, "Contribution of impaired Nrf2-Keap1 pathway to oxidative stress and inflammation in chronic renal failure," American Journal of Physiology, vol. 298, no. 3, pp. F662-F671, 2010.

[51] H. Motohashi and M. Yamamoto, "Nrf2-Keap1 defines a physiologically important stress response mechanism," Trends in Molecular Medicine, vol. 10, no. 11, pp. 549-557, 2004.

[52] M. Kobayashi, L. Li, N. Iwamoto et al., "The antioxidant defense system Keap1-Nrf2 comprises a multiple sensing mechanism for responding to a wide range of chemical compounds," Molecular and Cellular Biology, vol. 29, no. 2, pp. 493-502, 2009.

[53] S. A. Chanas, Q. Jiang, M. McMahon et al., "Loss of the Nrf2 transcription factor causes a marked reduction in constitutive and inducible expression of the glutathione S-transferase Gsta1, Gsta2, Gstm1, Gstm2, Gstm3 and Gstm4 genes in the livers of male and female mice," Biochemical Journal, vol. 365, no. 2, pp. 405-416, 2002.

[54] S. A. Reisman, R. L. Yeager, M. Yamamoto, and C. D. Klaassen, "Increased Nrf2 activation in livers from keap1-knockdown mice Increases expression of cytoprotective genes that detoxify electrophiles more than those that detoxify reactive oxygen species," Toxicological Sciences, vol. 108, no. 1, pp. 35-47, 2009.

[55] J. L. Ning, L. W. Mo, and X. N. Lai, "Low-and high-dose hydrogen peroxide regulation of transcription factor NF-E2related factor 2," Chinese Medical Journal, vol. 123, no. 8, pp. 1063-1069, 2010.

[56] A. I. Rojo, P. Rada, J. Egea, A. O. Rosa, M. G. López, and A. Cuadrado, "Functional interference between glycogen synthase kinase- 3 beta and the transcription factor Nrf2 in protection against kainate-induced hippocampal celldeath," Molecular and Cellular Neuroscience, vol. 39, no. 1, pp. 125132,2008

[57] O. O. Erejuwa, S. A. Sulaiman, M. S. ab Wahab, S. K.N. Salam, M. S. md Salleh, and S. G. Gurtu, "Comparison of antioxidant effects of honey, glibenclamide, metformin, and their combinations in the kidneys of streptozotocin-induced diabetic rats," International Journal of Molecular Sciences, vol. 12, no. 1, pp. 829-843, 2011.

[58] D. Binda, L. Nicod, C. Viollon-Abadie et al., "Strain difference (WKY, SPRD) in the hepatic antioxidant status in rat and effect of hypertension (SHR, DOCA). Ex vivo and in vitro data," Molecular and Cellular Biochemistry, vol. 218, no. 1-2, pp. 139-146, 2001.

[59] K. C. Kregel and H. J. Zhang, "An integrated view of oxidative stress in aging: basic mechanisms, functional effects, and pathological considerations," American Journal of Physiology, vol. 292, no. 1, pp. R18-R36, 2007.

[60] P. Gomes, S. Simão, E. Silva et al., "Aging increases oxidative stress and renal expression of oxidant and antioxidant enzymes that are associated with an increased trend in systolic blood pressure," Oxidative Medicine and Cellular Longevity, vol. 2, no. 3, pp. 138-145, 2009.

[61] B. Ghosh, C. D. Hanevold, K. Dobashi, J. K. Orak, and I. Singh, "Tissue differences in antioxidant enzyme gene expression in response to endotoxin," Free Radical Biology and Medicine, vol. 21, no. 4, pp. 533-540, 1996.

[62] S. P. Gygi, Y. Rochon, B. R. Franza, and R. Aebersold, "Correlation between protein and mRNA abundance in yeast,"
Molecular and Cellular Biology, vol. 19, no. 3, pp. 1720-1730, 1999.

[63] T. J. Griffin, S. P. Gygi, T. Ideker et al., "Complementary profiling of gene expression at the transcriptome and proteome levels in Saccharomyces cerevisiae," Molecular \& Cellular Proteomics, vol. 1, no. 4, pp. 323-333, 2002.

[64] D. García-López, K. Häkkinen, M. J. Cuevas et al., "Effects of strength and endurance training on antioxidant enzyme gene expression and activity in middle-aged men," Scandinavian Journal of Medicine and Science in Sports, vol. 17, no. 5, pp. 595-604, 2007.

[65] M. Arciello, C. R. Capo, S. D’Annibale et al., "Copper depletion increases the mitochondrial-associated SOD1 in neuronal cells," BioMetals, vol. 24, no. 2, pp. 269-278, 2010.

[66] M. F. Tsan, J. E. White, C. Treanor, and J. B. Shaffer, "Molecular basis for tumor necrosis factor-induced increase in pulmonary superoxide dismutase activities," American Journal of Physiology, vol. 259, no. 6, pp. L506-L512, 1990.

[67] L. B. Clerch and D. Massaro, "Tolerance of rats to hyperoxia. Lung antioxidant enzyme gene expression," The Journal of Clinical Investigation, vol. 91, no. 2, pp. 499-508, 1993.

[68] H. Ohkawa, N. Ohishi, and K. Yagi, "Assay for lipid peroxides in animal tissues by thiobarbituric acid reaction," Analytical Biochemistry, vol. 95, no. 2, pp. 351-358, 1979.

[69] D. Koracevic, G. Koracevic, V. Djordjevic, S. Andrejevic, and V. Cosic, "Method for the measurement of antioxidant activity in human fluids," Journal of Clinical Pathology, vol. 54, no. 5, pp. 356-361, 2001.

[70] L. Goth, "A simple method for determination of serum catalase activity and revision of reference range," Clinica Chimica Acta, vol. 196, no. 2-3, pp. 143-151, 1991.

[71] D. M. Goldberg and R. J. Spooner, "Assay of glutathione reductase," in Methods of Enzymatic Analysis, H. V. Bergmeyen, Ed., pp. 258-265, Chemie, Weinheim, Germany, 1983.

[72] W. H. Habig, M. J. Pabst, and W. B. Jakoby, "Glutathione $S$ transferases. The first enzymatic step in mercapturic acid formation," The Journal of Biological Chemistry, vol. 249, no. 22, pp. 7130-7139, 1974.

[73] M. M. Bradford, "A rapid and sensitive method for the quantitation of microgram quantities of protein utilizing the principle of protein dye binding," Analytical Biochemistry, vol. 72, no. 1-2, pp. 248-254, 1976.

[74] S. Chattopadhyay, D. K. Sahoo, U. Subudhi, and G. B. N. Chainy, "Differential expression profiles of antioxidant enzymes and glutathione redox status in hyperthyroid rats: a temporal analysis," Comparative Biochemistry and Physiology-C, vol. 146, no. 3, pp. 383-391, 2007.

[75] S. W. Zangen, S. Ryu, and A. Ornoy, "Alterations in the expression of antioxidant genes and the levels of transcription factor NF-Kappa B in relation to diabetic embryopathy in the cohen diabetic rat model," Birth Defects Research Part AClinical and Molecular Teratology, vol. 76, no. 2, pp. 107-114, 2006.

[76] G. Li, P. Xie, H. Li et al., "Acute effects of microcystins on the transcription of 14 glutathione S-transferase isoforms in Wistar rat," Environmental Toxicology, vol. 26, no. 2, pp. 187194, 2011.

[77] B. Bauer, A. M. S. Hartz, J. R. Lucking, X. Yang, G. M. Pollack, and D. S. Miller, "Coordinated nuclear receptor regulation of the efflux transporter, Mrp2, and the phase-II metabolizing enzyme, GST $\pi$, at the blood-brain barrier," Journal of Cerebral Blood Flow and Metabolism, vol. 28, no. 6, pp. 1222-1234, 2008 . 
[78] H. Y. Li, S. Y. Wu, and N. Shi, "Transcription factor Nrf2 activation by deltamethrin in PC12 cells: involvement of ROS," Toxicology Letters, vol. 171, no. 1-2, pp. 87-98, 2007.

[79] K. J. Livak and T. D. Schmittgen, "Analysis of relative gene expression data using real-time quantitative PCR and the 2$\Delta \Delta$ CT method," Methods, vol. 25, no. 4, pp. 402-408, 2001. 


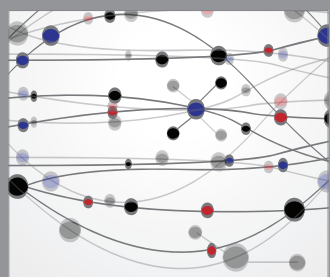

The Scientific World Journal
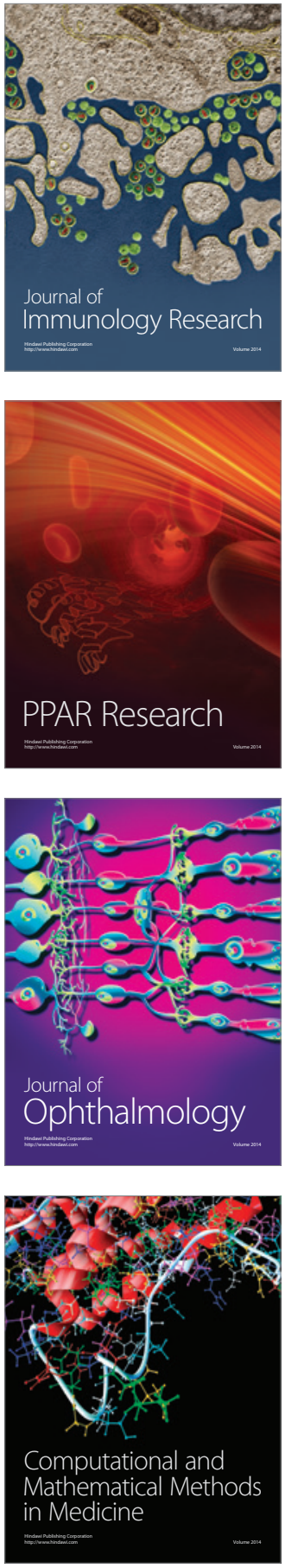

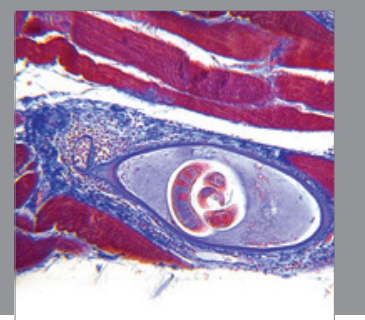

Gastroenterology

Research and Practice
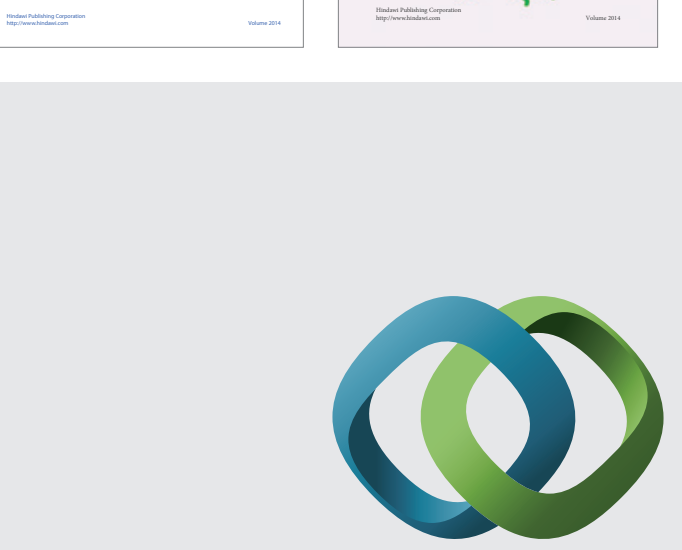

\section{Hindawi}

Submit your manuscripts at

http://www.hindawi.com
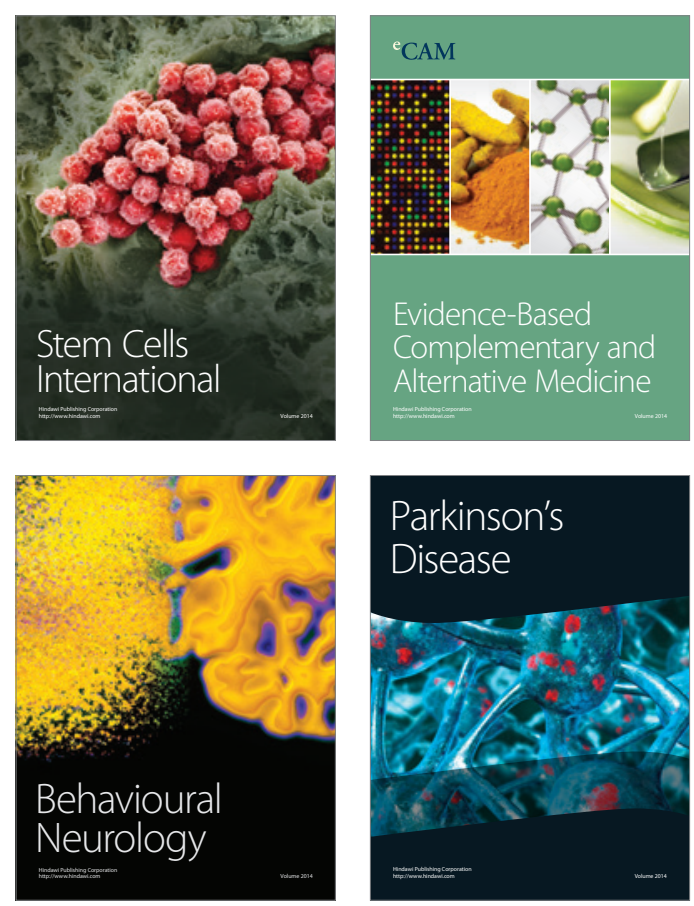

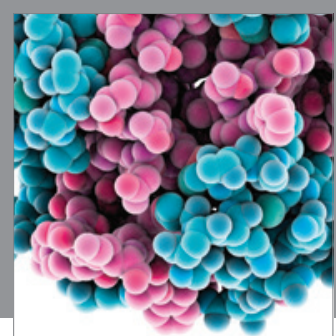

Journal of
Diabetes Research

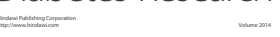

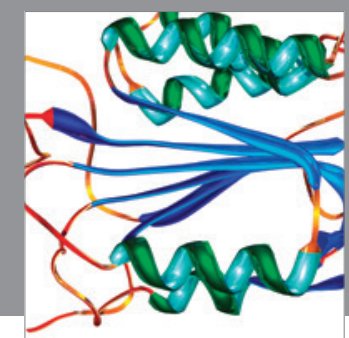

Disease Markers
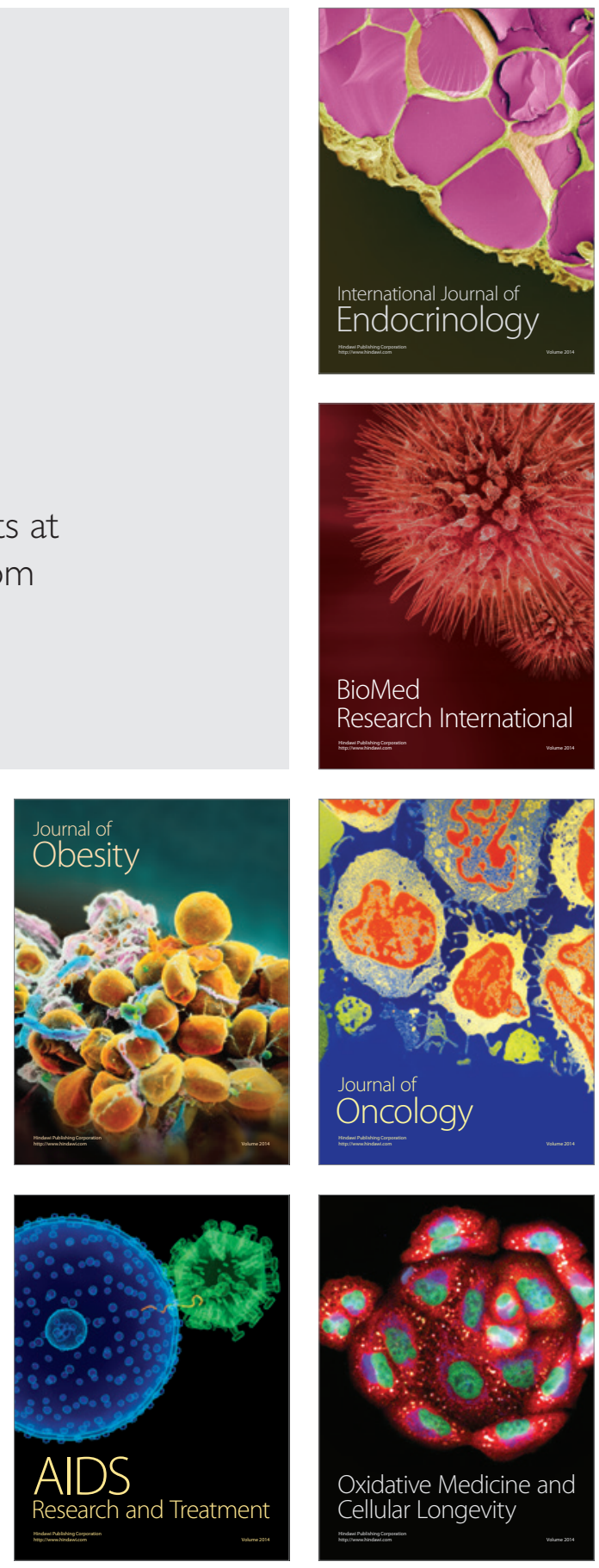